\title{
Critical Thinking and It is Role in Facing Coronavirus
}

\author{
Violla Makhzoum ${ }^{1}$, Mazen Jabbour ${ }^{2}$
}

\section{ARTICLE INFO}

Article History:

Received 26.03.2019

Received in revised form

14.08.2020

Accepted

Available online 01.10.2020

\begin{abstract}
This research addresses the role of the Critical thinking skill in helping individuals face the crisis that arise; and we have taken the spread of Corona virus as a model to build upon this study. This research uses the descriptive method to test the validity of research hypotheses based on correlations or influence between research variables. We adopted the random sampling to carry out with this study.In this study, we have used the questionnaire as a tool to study the sample that consisted of 500 citizens from all Lebanese governorates. The analysis of the field study showed that there is significant correlation between the respondents having the skill of Critical thinking, the anxiety resulting from the spread of Corona virus, and the role of this skill in adhering to the instructions issued by the Ministry of Health and the Ministry of Interior during the spread of this virus.It was proven in this research that Critical thinking skills were higher in women than it is for men; despite the result of the statistical analysis showing that women suffer more than men from anxiety and stress due to the spread of Corona virus.The ranking of the Lebanese provinces for the possession of Critical thinking skill was as follows: Beirut Governorate, Nabatiyeh Governorate, Mount Lebanon Governorate, South Lebanon Governorate, Bekaa Governorate, North Lebanon Governorate, Akkar Governorate, and Baalbek Hermel Governorate.
\end{abstract}

CC IJERE. All rights reserved

Keywords:12

Critical thinking, corona virus, twenty-first century

\section{INTRODUCTION}

Critical thinking is the ability to analyze and interpret information from an unbiased point of view, and to provide relevant solutions (Paul \& Elder, 2019). It is an essential skill because it helps individuals and groups analyze problems with efficiency, speed, and identify potential risks that are not explicit. Similarly, Critical thinking showed that during a particular crisis; like the pandemic outbreak of Corona virus, individuals are better placed in generating and evaluating different ideas, and choosing the most effective one (Lohrmann, 2011). Therefore, there is an equivocal necessity in this Corona pandemic, to the presence of the Critical thinking skill. Yet, the best way to improve this thinking and develop it, is to have access to necessary and reliable information of the virus in order to enable us to face it in a rational way to better confront it and limit its spread. This will eventually contribute in decreasing the current undergoing crisis in general, and make us ready to face any future upcoming crises (Lemon, \& all, 2008).

The Corona pandemic has gained a lot of attention and hustle in the media, and many are prone to being misled. For that reason, we have researched in this paper the role that the Critical thinking has in supporting individuals contain the emerging crisis that might occur in Lebanon, and the resulting changes and developments in the surrounding environment; especially in terms of diseases and serious epidemics that are viral across borders and continents, killing millions of people (Hopkins, Surda, \& Kumar, 2020). Today, the most prominent challenge facing the world is to maintain good health of its population because these epidemics equalize the seriousness of natural disasters and climate changes, as well as it negatively reflects all sectors in the country; especially the economy, tourism, and agriculture. Hence the importance of acquiring and developing the skill of Critical thinking will help societies draw up scenarios related to finding solutions to expected risks, and proactively work on preventing their occurrence. Corona virus will not be the last virus, or the last biological war which humanity will largely and unfamiliarly face in the twenty-first century. Therefore, we should not remain satisfied with what we have, rather we should together strive to seek new scientific discoveries to confront upcoming medical, economic, social, or any other type of crisis.

The problem started to aggravate in parallel to the dominance of virtual social networks during the Corona pandemic; we all should have a moral responsibility by checking the authenticity of the news and the credibility of its source before publishing it (Makhzoum, 2020), as these platforms should not be used to spread false information that conflicts with the principles, values, and cultures. By instinct, humans tend to

'Corresponding e-mail: violla.makhzoum@iul.edu.lb, Islamic University of Lebanon, orcid.org/0000-0002-0462-5484

2 Corresponding e-mail: mazenjabbour@yahoo.com,orcid.org/0000-0002-5013-4205 
communicate with each other's by means of transferring and receiving information of different types and purposes (Levinson, 2016). For that reason, such communication should occur within specific norms and frameworks that meet the needs and desire of society in a positive and objective way. Rumors nowadays travel worldwide within fractions of a second.

To deliberately create confusion in countries having crisis- as is occurring in our societies today, and the way of administering the spread of the Corona pandemic is an aggressive behavior of an irresponsible person (Makhzoum, v., 2020). Nevertheless, many social network users intend to publish unreliable information that may threaten security or cause panic among people; supporting the saying that states that a rumor is created by the spiteful, published by the idiot, and believed by the stupid. This is the most dangerous psychological warfare tool. Based on the above, the research problem is determined in the evolutions of the twenty first century, and what digital control imposes on the different aspects of life, that can only be dealt with by acquiring a series of necessary skills and competencies. Such skills allow individuals to participate in a fast-moving and evolving society. This has prompted us to study the relationship between acquiring and developing the skill of critical thinking and facing emerging crisis.

Theories conducted about the skill of critical thinking suggest that it is a set of ideas, thoughts and beliefs about the meaning of critical thinking; and studying those theories is important because the facilitate the retention of the materialistic information related to the concept, as those theories contribute in organizing the ideas and influence the scientific explanations upon which the research problem and procedures are built (Havigerová, 2011). We may also find a whole series of concepts through which individuals explore the concept of critical thinking (Rainbolt and Dwyer, 205, p.5). Cottrel says "critical thinking is the skill of correctly evaluating the arguments presented by other people, and composing your own strong arguments" (2011, p.2). Liu, Frankel \& Roohl (2014) realize that the concept of critical thinking is considered a complex process of deliberations which involves a wide range of skills and trends. These skills and attitudes include identifying others' attitudes, arguments and conclusions, or evaluating the evidence of alternative perspectives; like the elements that are related to the theory of controversy. As per Van den Brink-Budgen (2010, p.1), these skills and attitudes point to the fact that people may not be able to think critically for personal or emotional reasons , which may create barriers such as insufficient focus and attention to details, or the inability to acknowledge the existence of many ways to look at the problem. Another opinion presented by Petty (2009), relates critical thinking with evaluation; like thinking in a way that allows us to identify the strength and weaknesses in our thinking to improve them. Based on the latter, we have strove in this research to study the role which "critical thinking" plays in emerging crisis and the extent of its impact on citizens' awareness, coexistence, and resolution of these crises.

\section{Research Questions}

Does the ownership of the skill of critical thinking contribute in the enhancement of the individual's physical and psychological health?

Does the ownership of the skill of critical thinking limits the speed of the spread of the Coronavirus in the country?

Do demographic data (gender, age, educational level, title) play a role in an individual's skill of critical thinking and problem solving?

Research Hypothesis

Hypothesis one: There exists a statistically significant relationship between the individual having the skill of critical thinking and the promotion of his physical and psychological health.

Hypothesis two: There exists a statistically significant relationship between the individual having the skill of critical thinking and problem solving, and limiting the speed of spreading the Corona virus.

Hypothesis three: There exists statistically significant differences between people's demographic data and their skill in critical thinking and problem solving. 


\section{METHOD}

In this paper, we have used the quantitative research methodology in collecting and analyzing the data of the field study (Sogunro, 2002). We have targeted citizens in all Lebanese governorates with questionnaires, following the random sampling method, and throughout the country via digital means; like, Linked in, Twitter, Telegram, Whatsapp, etc. This questionnaire was also published on certain news sites in order to reach the largest number of citizens covering the whole Lebanese territory, to reach a total of 500 participants from all governorates.

\section{Data Analysis:}

After filling the questionnaires, data was entered using statistical software called Statistical Package for Social Science (SPSS 25). Data was analyzed using the descriptive and the inferential statistics to test the hypothesis formulated on the importance of having the skill of Critical thinking in facing emerging crisis, like the Corona virus.

\section{FINDINGS}

The findings of the research are included in this section; we have generated demographic results of the survey, and in the Inferential statistics part, all the sections were compared by these demographics. All hypotheses of the research were tested as well.

\section{Demographic Results:}

By demography, we mean the quantitative characteristics of the respondents to this survey, which include their gender and age, in addition to their qualitative characteristics which include their social factors such as university specialty and the duration of their work at school.

The demographic results were as follows:

\section{Figure 1. Distribution of citizens according to Governorate}

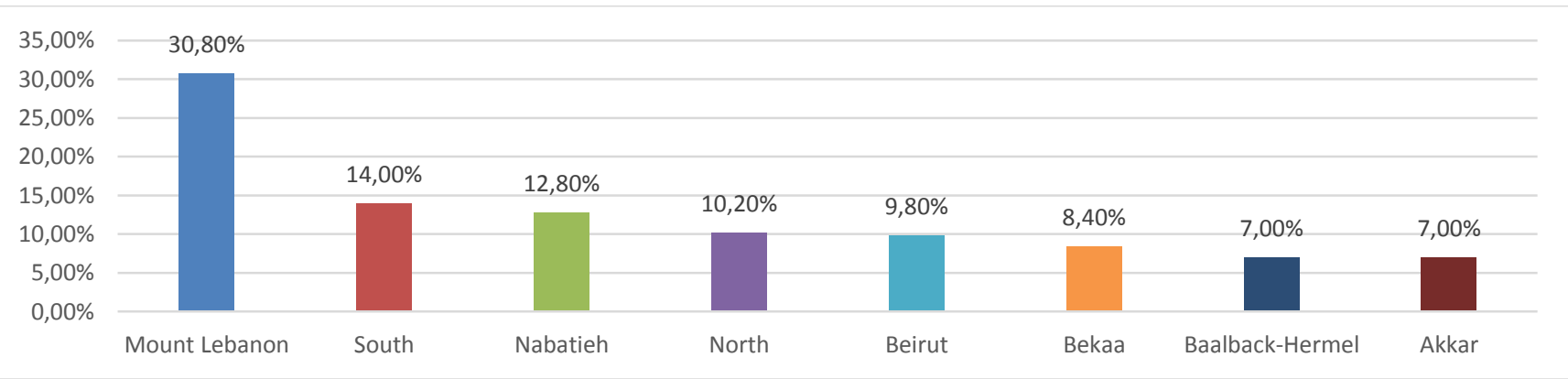

Figure 1 shows that the majority of the respondents who answered this questionnaire were from Mount Lebanon $(30.80 \%)$ and the minority of the respondents who answered this questionnaire were from Akkar.

Figure 2. Distribution of citizens according to Gender variable

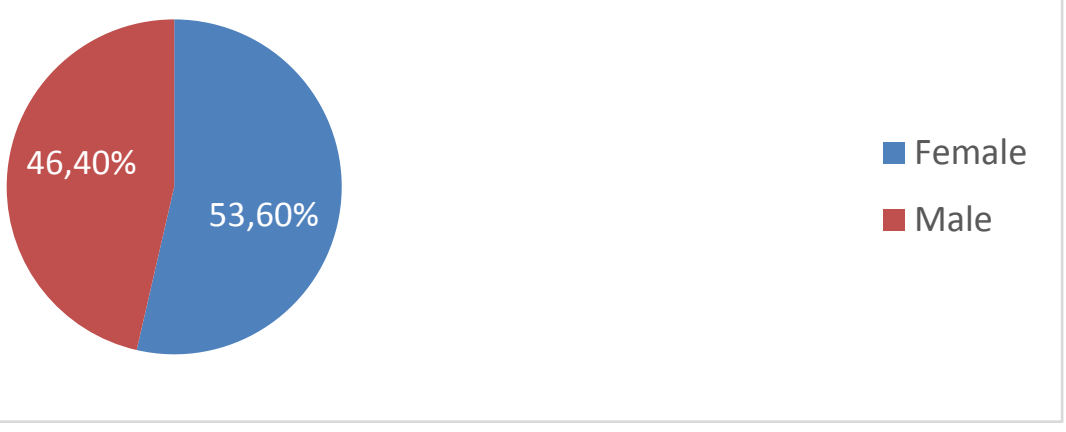

Figure 2 shows that the percentage of females who contributed in this survey was $53.60 \%$, while the percentage of males who contributed in this survey was $46.40 \%$. 
Figure 3. Distribution of citizens according to Age variable

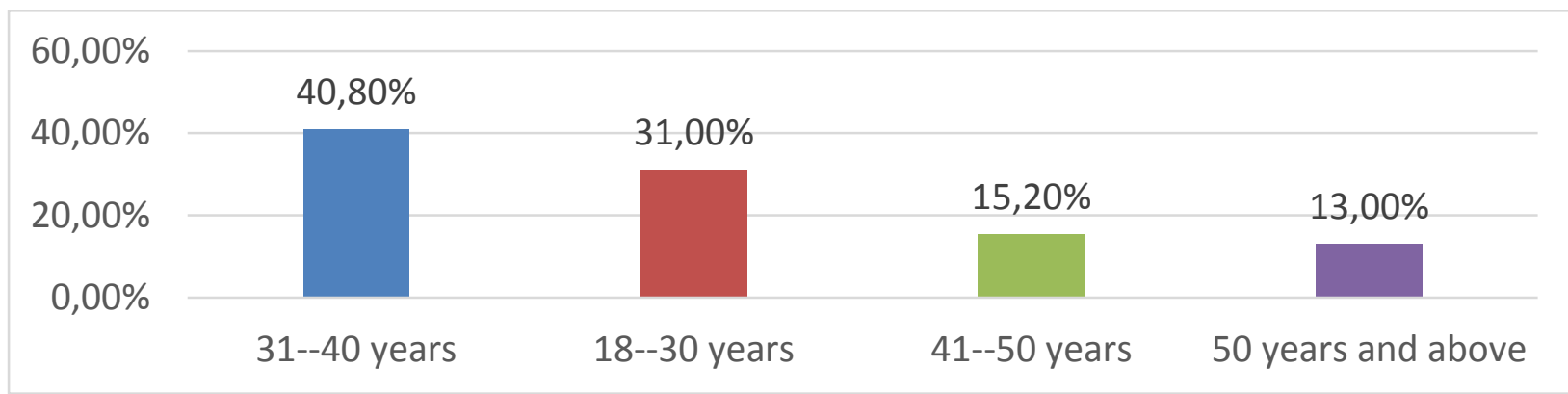

Figure 3 shows that that highest percentage for citizens whose age ranged between 31 - 40 years was $40.80 \%$. Next, citizens whose age ranged between 18 - 30 years had a percentage of $31 \%$. For those citizens whose age ranged between $41-50$ years, their percentage was $15.20 \%$. And the last category, which was for citizens aged 50 years and over, their percentage was $13 \%$.

Figure 4. Distribution of citizens according to Education

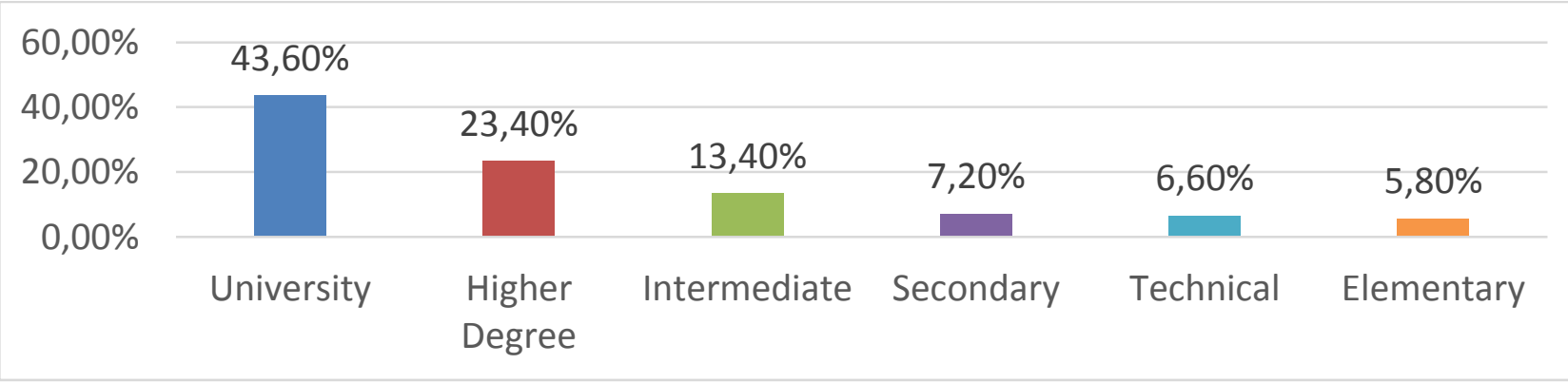

Figure 4 shows that the highest percentage $43.60 \%$ was for the citizens holders of a university degree (BS), and the rest of the ratios were distributed between $23.40 \%$ higher degree (MS, PHD), $13.40 \%$ Intermediate school level, $7.20 \%$ for holders of school certificates (secondary level), $6.60 \%$ for holders of Technical certificates, and $5.80 \%$ which is the lowest percentage for citizens who have not completed their education from the school elementary level.

\section{Figure 5. Distribution of citizens according to chronic diseases}

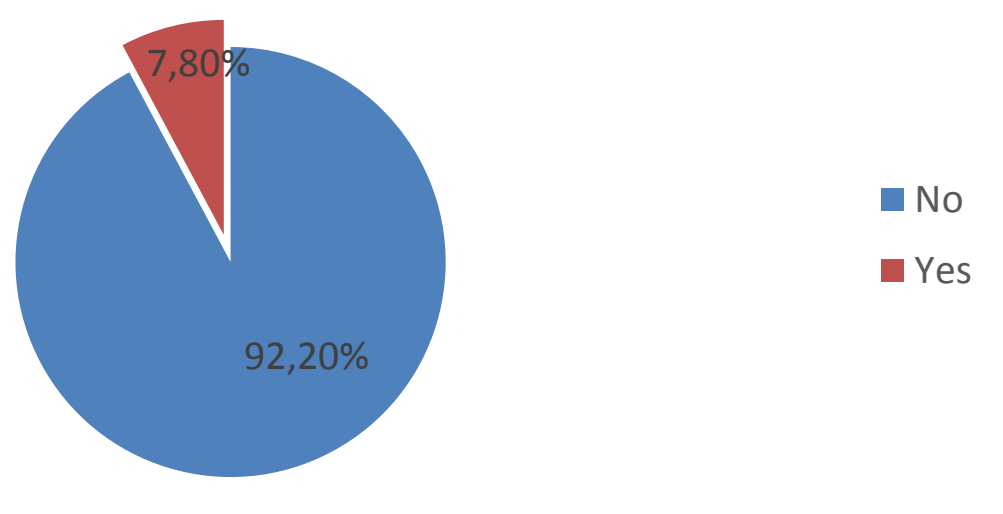

Figure 5 shows that the percentage of citizens who answered this survey suffer from chronic diseases is $7.8 \%$, compared to $92.2 \%$ of citizens who answered this survey do not suffer from chronic diseases. 
Figure 6. Distribution of citizens according to Type of chronic disease

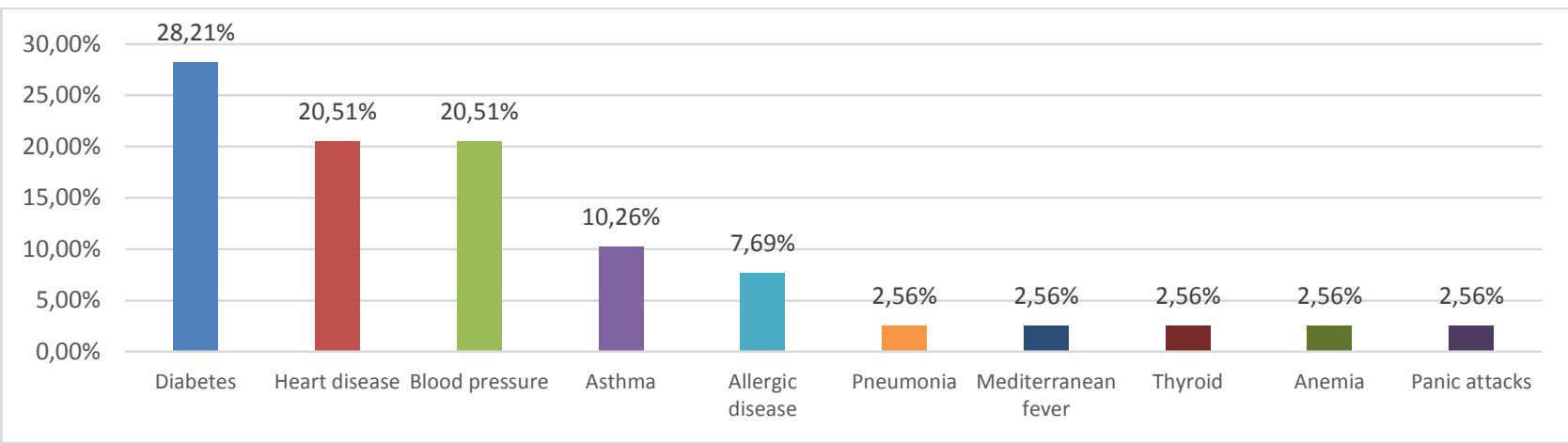

Figure 6 shows that citizens who were included in the sample and suffer from chronic diseases suffer from ten types of diseases, the highest percentage $28.21 \%$ was for citizens who suffer from diabetes, and the lowest percentage $2.56 \%$ was for citizens who suffer from panic attacks.

Figure 7. Distribution of citizens according to Social status

\begin{tabular}{|c|c|c|c|c|}
\hline $100,00 \%$ & $64,00 \%$ & & & \\
\hline $50,00 \%$ & & $29,20 \%$ & $3.80 \%$ & $3.00 \%$ \\
\hline $0,00 \%$ & Married & Single & Divorced & Widowed \\
\hline
\end{tabular}

Figure 7 shows that the percentage of married couples among citizens who were included in the sample was $64 \%$ compared to $29.20 \%$ of citizens who were single, $3.80 \%$ were divorced citizens and $3 \%$ were widowed citizens.

\section{Inferential analysis of responses to Corona virus:}

\section{Section one: Anxiety due to Corona virus:}

The questions in this survey related to Anxiety from Corona were Likert scale of 5 points where, $1=$ strongly disagree, $2=$ disagree, $3=$ neutral, $4=$ agree, and $5=$ strongly agree. The more close to 5 was the mean, the more anxious were the respondents.

The questions were:

1. Corona virus caused me great concern.

2. I fear a lot for my family from corona virus.

3. I fear shopping in crowded places

Figure 8. Anxiety due to Corona virus variables means

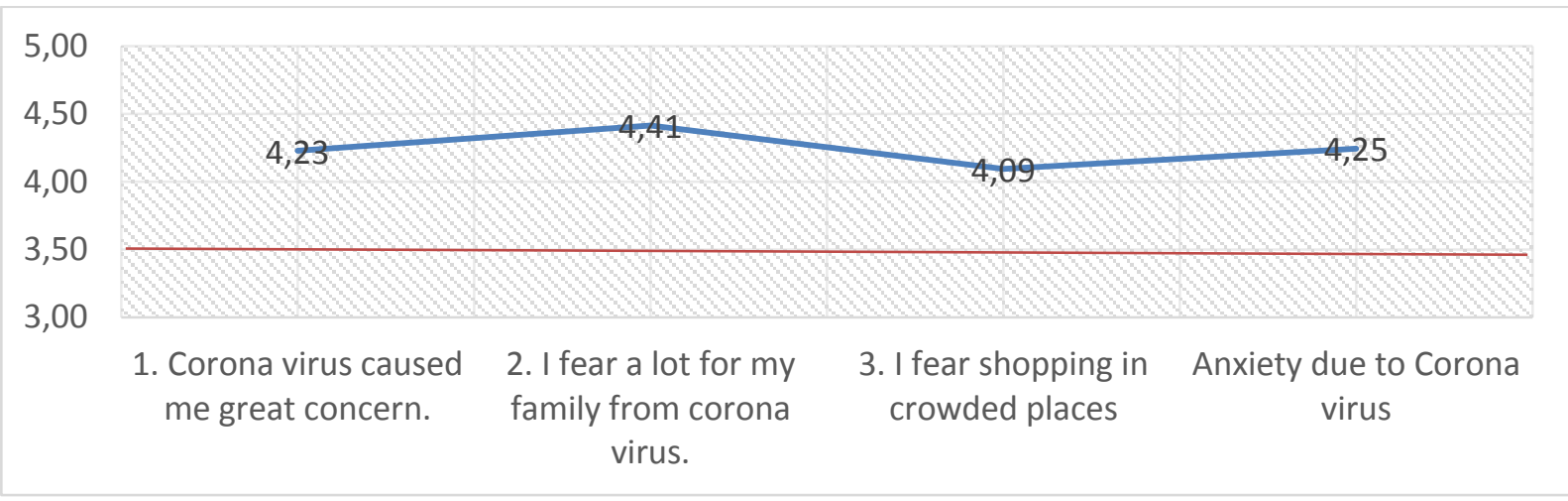


Figure 8 shows that the highest level of anxiety was for question 2 which had a mean of 4.41; the closest to 5. The next level of anxiety was for the overall score of those 3 questions (mean of 4.25). Then, question 1 has a mean of 4.23 for people having great concern caused by Corona virus. The lowest mean was 4.09 related to question 3, which is the fear of shopping in crowded places. Regardless of the differences in the means between the responses of those 3 questions, we note that all of them are above 3.5 - the threshold to starting having anxiety (point 3 in the Likert scale being Neutral).

We have adopted the One-Sample test to compare the means for the first section related to the anxiety caused by Corona virus to citizens with the average mean of 3.5 in table 1 as follows:

Comparing the means of the first section with 3.5 (Table 1.)

\begin{tabular}{|c|c|c|c|c|}
\hline Variable & Mean & Mean:3.5 & $\begin{array}{l}\text { P-value } \\
\text { (1-tailed) }\end{array}$ & Interpretation \\
\hline $\begin{array}{l}\text { 1. Corona virus caused } \\
\text { me great concern. }\end{array}$ & 4.23 & 0.73 & 0.00 & $\begin{array}{l}\text { The P-value is less than } 0.05 \text { / } \\
\text { the difference between the mean } \\
\text { and } 3.5 \text { is positive / There is a } \\
\text { statistical significance that the } \\
\text { mean is greater than } 3.5\end{array}$ \\
\hline $\begin{array}{l}\text { 2. I fear a lot for my } \\
\text { family from corona } \\
\text { virus. }\end{array}$ & 4.41 & 0.91 & 0.00 & $\begin{array}{l}\text { The P-value is less than } 0.05 \text { / } \\
\text { the difference between the mean } \\
\text { and } 3.5 \text { is positive / There is a } \\
\text { statistical significance that the } \\
\text { mean is greater than } 3.5\end{array}$ \\
\hline $\begin{array}{l}\text { 3. I fear shopping in } \\
\text { crowded places. }\end{array}$ & 4.09 & 0.59 & 0.00 & $\begin{array}{l}\text { The P-value is less than } 0.05 \text { / } \\
\text { the difference between the mean } \\
\text { and } 3.5 \text { is positive / There is a } \\
\text { statistical significance that the } \\
\text { mean is greater than } 3.5\end{array}$ \\
\hline $\begin{array}{l}\text { Anxiety due to } \\
\text { Corona virus }\end{array}$ & 4.25 & 0.75 & 0.00 & $\begin{array}{l}\text { The P-value is less than } 0.05 \text { / } \\
\text { the difference between the mean } \\
\text { and } 3.5 \text { is positive / There is a } \\
\text { statistical significance that the } \\
\text { mean is greater than } 3.5\end{array}$ \\
\hline
\end{tabular}

Table 1 shows that all the means are greater than 3.5 (all $\mathrm{P}$ values are less than 0.05 ); and thus, there is a statistical evidence that Corona virus created anxiety among citizens.

Section Two: Commitment of citizens towards the instructions of the Ministry of Health and the Ministry of Interior.

The questions in this survey related to Anxiety from Corona were Likert scale of 5 points where, $1=$ strongly disagree, $2=$ disagree, $3=$ neutral, $4=$ agree, and $5=$ strongly agree. The more close to 5 was the mean, the more committed were the respondents.

The questions were:

4. I adhered to all health preventive measures recommended by the Ministry of Health.

5. I was committed to home quarantine.

6. I adhered to the pair / impair vehicle plate numbers commuting through week days.

Figure 9. Commitment of citizens towards the instructions of the Ministry of Health and the Ministry of Interior variables means 


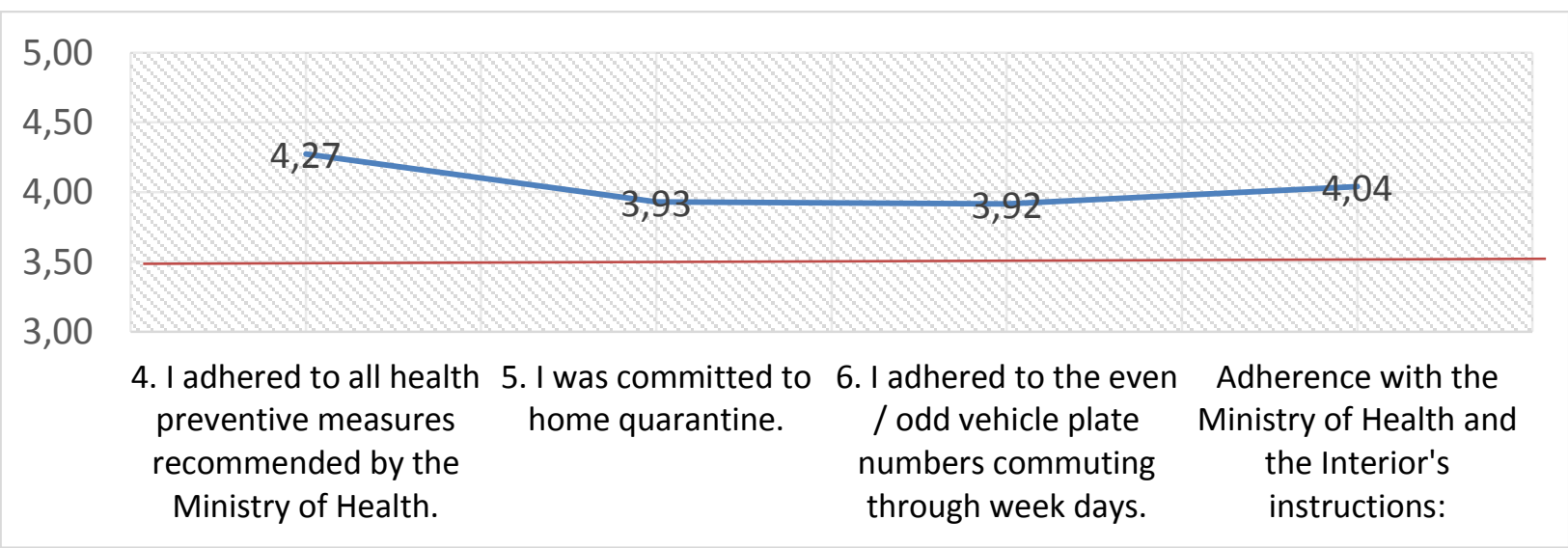

Figure 9 shows that the highest level of commitment was for question 4 which had a mean of 4.27 ; the closest to 5. The next level of commitment was for the overall score of those 3 questions (mean of 4.04). Then, question 5 has a mean of 3.93 for people committed to home quarantine. The lowest mean was 3.92 related to question 6, which is adhered to the pair / impair vehicle plate numbers commuting through week days. Regardless of the differences in the means between the responses of those 3 questions, we note that all of them are above 3.5 - the threshold to commitment to instructions (point 3 in the Likert scale being Neutral).

We have adopted the One-Sample test to compare the means for the second section related to commitment of citizens to the instructions of the Ministry of Health and the Ministry of Interior with the average mean of 3.5 in table 2 as follows:

Comparing the means of the second section with 3.5 (Table 2.)

\begin{tabular}{|c|c|c|c|c|}
\hline Variable & Mean & Mean & $\begin{array}{l}\text { Pvalue( } \\
\text { 1-tailed) }\end{array}$ & Interpretation \\
\hline $\begin{array}{l}\text { 4. I adhered to all health } \\
\text { preventive measures } \\
\text { recommended by the Ministry } \\
\text { of Health. }\end{array}$ & 4.27 & 0.77 & 0.00 & $\begin{array}{l}\text { The P-value is less than } 0.05 \\
\text { / the difference between the } \\
\text { mean and } 3.5 \text { is positive / There } \\
\text { is a statistical significance that } \\
\text { the mean is greater than } 3.5\end{array}$ \\
\hline $\begin{array}{l}\text { 5. I was committed to home } \\
\text { quarantine. }\end{array}$ & 3.93 & 0.43 & 0.00 & $\begin{array}{l}\text { The P-value is less than } 0.05 \\
\text { / the difference between the } \\
\text { mean and } 3.5 \text { is positive / There } \\
\text { is a statistical significance that } \\
\text { the mean is greater than } 3.5\end{array}$ \\
\hline $\begin{array}{l}\text { 6. I adhered to the even / } \\
\text { odd vehicle plate numbers } \\
\text { commuting through week } \\
\text { days. }\end{array}$ & 3.92 & 0.42 & 0.00 & $\begin{array}{l}\text { The P-value is less than } 0.05 \\
\text { / the difference between the } \\
\text { mean and } 3.5 \text { is positive / There } \\
\text { is a statistical significance that } \\
\text { the mean is greater than } 3.5\end{array}$ \\
\hline $\begin{array}{c}\text { Adherence with the Ministry } \\
\text { of Health and the Interior's } \\
\text { instructions }\end{array}$ & 4.04 & 0.54 & 0.00 & $\begin{array}{l}\text { The P-value is less than } 0.05 \\
\text { / the difference between the } \\
\text { mean and } 3.5 \text { is positive / There } \\
\text { is a statistical significance that } \\
\text { the mean is greater than } 3.5\end{array}$ \\
\hline
\end{tabular}


Table 2 shows that all the means are greater than 3.5 (all $\mathrm{P}$ values are less than 0.05); and thus, there is a statistical evidence that citizens were committed to the instructions of the Ministry of Health and the Ministry of Interior.

\section{Section Three: The effect of Corona virus on working citizens. ( $\mathrm{N}=299$ out of 500)}

The questions in this survey related to the effect on working citizens, were Likert scale of 5 points where, 1 = strongly disagree, 2 = disagree, 3 = neutral, $4=$ agree, and $5=$ strongly agree. The more close to 5 was the mean, the more effect had the Corona virus on working citizens.

The questions were:

7. I was laid off from work due to Corona virus.

8. I lost a part of my salary due to Corona virus.

9. I have accumulated debt due to Corona virus.

Figure 10. The effect of Corona virus on working citizens, variables means

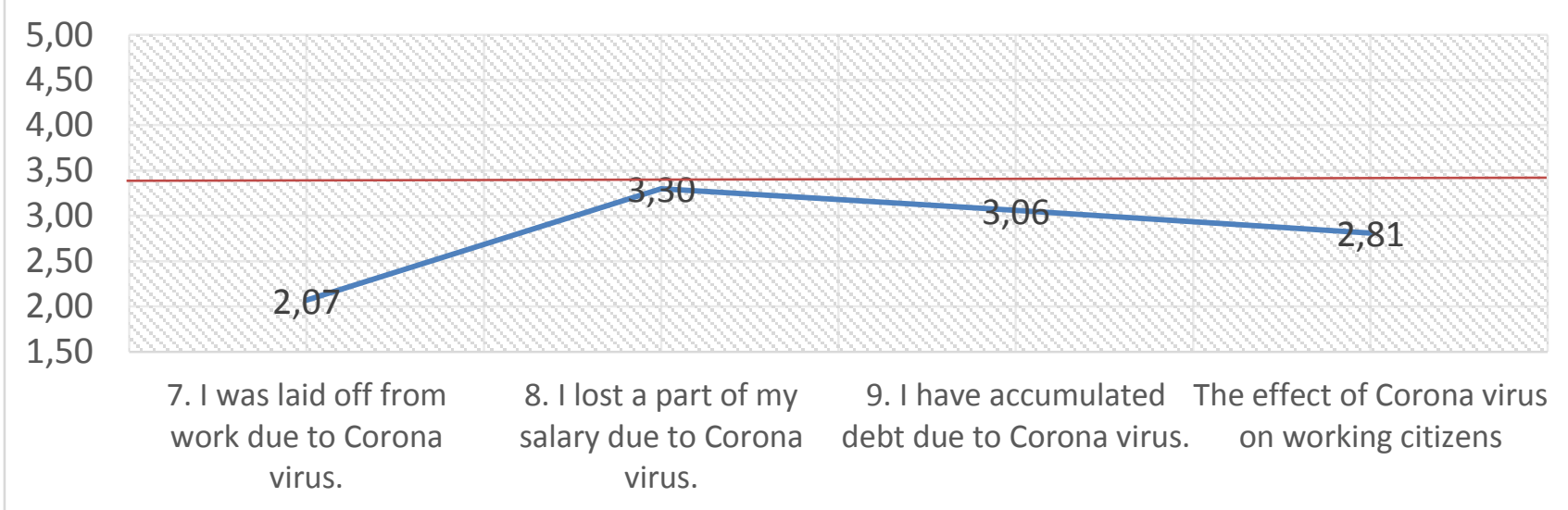

Figure 10 shows that the highest level of the effect of Corona virus was for question 8 which had a mean of 3.30; the closest to 3.5. The next level of commitment was for question 9 which had a mean of 3.06. Then, the overall score these 3 questions had a mean of 2.81 . The lowest mean was 2.07 related to question 7, which is being laid off from work. Regardless of the differences in the means between the responses of those 3 questions, we note that all of them are below 3.5 (point 3 in the Likert scale being Neutral). We have adopted the One-Sample test to compare the means for the third section related to the effect of Corona virus on working citizen with the average mean of 3.5 in Table 3 as follows: 
Comparing the means of the third section with 3.5 (Table 3)

\begin{tabular}{|c|c|c|c|c|}
\hline Variable & Mean & Mean 3.5 & $\begin{array}{l}\text { P-value } \\
\text { (1-tailed) }\end{array}$ & Interpretation \\
\hline $\begin{array}{l}\text { 7. I was laid off from } \\
\text { work due to Corona } \\
\text { virus. }\end{array}$ & 2.07 & -1.43 & 0.00 & $\begin{array}{l}\text { The P-value is less than } 0.05 \text { / } \\
\text { the difference between the mean } \\
\text { and } 3.5 \text { is negative / There is a } \\
\text { statistical significance that the } \\
\text { mean is less than } 3.5\end{array}$ \\
\hline $\begin{array}{l}\text { 8. I lost a part of } \\
\text { my salary due to } \\
\text { Corona virus. }\end{array}$ & 3.30 & -0.20 & 0.02 & $\begin{array}{l}\text { The P-value is less than } 0.05 \text { / } \\
\text { the difference between the mean } \\
\text { and } 3.5 \text { is negative / There is a } \\
\text { statistical significance that the } \\
\text { mean is less than } 3.5\end{array}$ \\
\hline $\begin{array}{l}\text { 9. I have accumulated } \\
\text { debt due to Corona } \\
\text { virus. }\end{array}$ & 3.06 & -0.44 & 0.00 & $\begin{array}{l}\text { The P-value is less than } 0.05 \text { / } \\
\text { the difference between the mean } \\
\text { and } 3.5 \text { is negative / There is a } \\
\text { statistical significance that the } \\
\text { mean is less than } 3.5\end{array}$ \\
\hline $\begin{array}{l}\text { The effect of Corona } \\
\text { virus on working } \\
\text { citizens }\end{array}$ & 2.81 & -0.69 & 0.00 & $\begin{array}{l}\text { The P-value is less than } 0.05 \text { / } \\
\text { the difference between the mean } \\
\text { and } 3.5 \text { is negative / There is a } \\
\text { statistical significance that the } \\
\text { mean is less than } 3.5\end{array}$ \\
\hline
\end{tabular}

Table 3 shows that all means are lower than 3.5 (all $\mathrm{P}$ values are less than 0.05 ); and this means there is a statistical evidence that Corona virus did not have a critical effect on working citizens.

Section Four: The extent to which citizens had critical thinking.

The questions in this survey related to the extent to which citizens had critical thinking, were Likert scale of 5 points where, $1=$ strongly disagree, $2=$ disagree, $3=$ neutral, $4=$ agree, and $5=$ strongly agree. The more close to 5 was the mean, the more critical thinking the citizens had.

The questions were:

10. I was following Corona virus news on a daily basis.

11. I was checking the reliability of the news sources of Corona virus prior publishing it.

12. I have researched info related to Corona virus through related websites.

13. I was following up the updates of Corona virus on social media.

14. I was consulting specialized doctors only for info related to Corona virus.

Figure 11. Critical thinking, variables means 


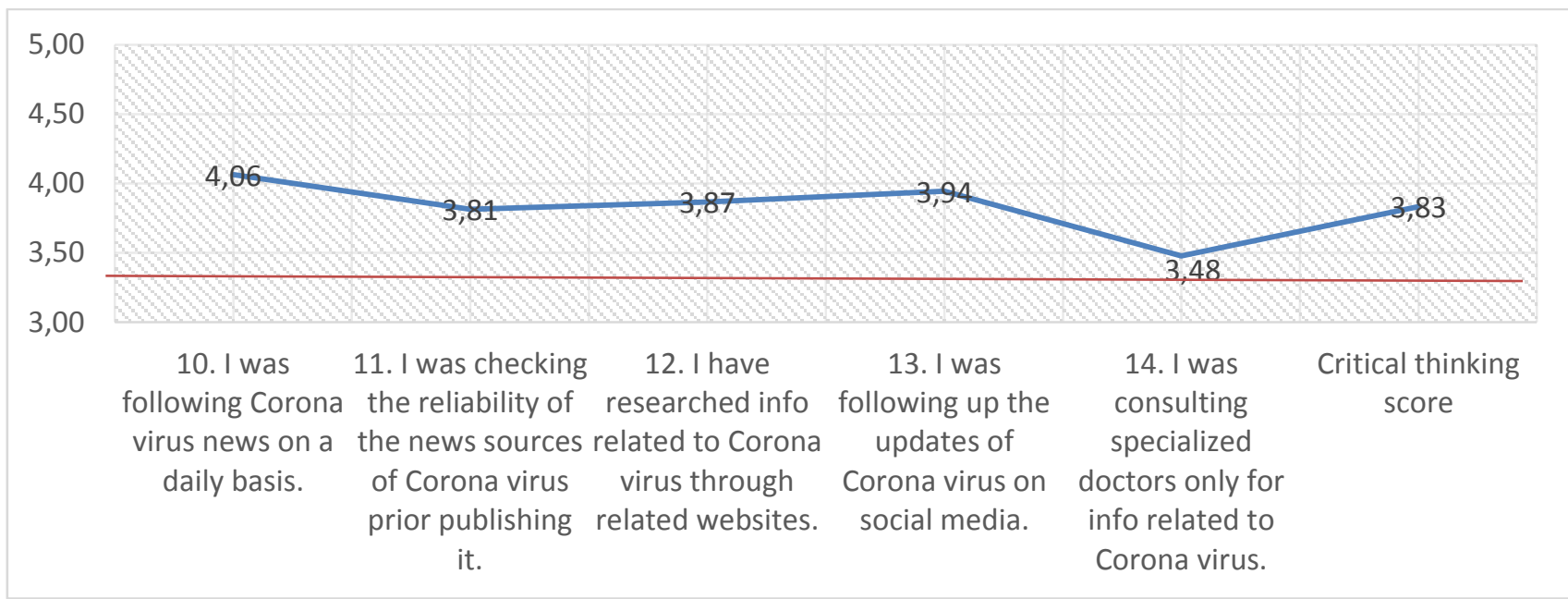

Figure 11 shows that highest level of the citizens having critical thinking was for question 10 which had a mean of 4.06; the closest to 5. The next level of availability of Critical thinking in citizens was for question 13 which had a mean of 3.94. Then, question 12 had a mean of 3.87. The overall score these 5 questions had a mean of 3.83, and question 11 had a mean of 3.81. The lowest mean was 3.48 related to question 14, which consulting specialized doctors only. Regardless of the differences in the means between the responses of those 5 questions, we note that all of them are below 3.5 (point 3 in the Likert scale being Neutral) except consulting specialized doctors only for info related to Corona virus; it was lower than the 3.5 average mean.

We have adopted the One-Sample test to compare the means for the fourth section related to the extent of Critical thinking available in citizens of this survey with the average mean of 3.5 in table 4 as follows:

Comparing the means of the fourth section with 3.5 (Table 4.)

\begin{tabular}{|c|c|c|c|c|}
\hline Variable & Mean & Mean & $\begin{array}{l}\text { P-value } \\
\text { (1-tailed) }\end{array}$ & Interpretation \\
\hline $\begin{array}{l}\text { 10. I was following } \\
\text { Corona virus news on a } \\
\text { daily basis. }\end{array}$ & 4.06 & 0.56 & 0.00 & $\begin{array}{l}\text { The P-value is less than } 0.05 / \text { the } \\
\text { difference between the mean and } 3.5 \text { is positive / } \\
\text { There is a statistical significance that the mean is } \\
\text { greater than } 3.5\end{array}$ \\
\hline $\begin{array}{l}\text { 11. I was checking the } \\
\text { reliability of the news } \\
\text { sources of Corona virus } \\
\text { prior publishing it. }\end{array}$ & 3.81 & 0.31 & 0.00 & $\begin{array}{l}\text { The P-value is less than } 0.05 / \text { the } \\
\text { difference between the mean and } 3.5 \text { is positive / } \\
\text { There is a statistical significance that the mean is } \\
\text { greater than } 3.5\end{array}$ \\
\hline $\begin{array}{l}\text { 12. I have researched } \\
\text { info related to Corona virus } \\
\text { through related websites. }\end{array}$ & 3.87 & 0.37 & 0.00 & $\begin{array}{l}\text { The P-value is less than } 0.05 / \text { the } \\
\text { difference between the mean and } 3.5 \text { is positive / } \\
\text { There is a statistical significance that the mean is } \\
\text { greater than } 3.5\end{array}$ \\
\hline $\begin{array}{l}\text { 13. I was following up } \\
\text { the updates of Corona virus } \\
\text { on social media. }\end{array}$ & 3.94 & 0.44 & 0.00 & $\begin{array}{l}\text { The P-value is less than } 0.05 / \text { the } \\
\text { difference between the mean and } 3.5 \text { is positive / } \\
\text { There is a statistical significance that the mean is } \\
\text { greater than } 3.5\end{array}$ \\
\hline $\begin{array}{l}\text { 14. I was consulting } \\
\text { specialized doctors only for } \\
\text { info related to Corona virus. }\end{array}$ & 3.48 & -0.02 & 0.69 & $\begin{array}{l}\text { The P-value is less than } 0.05 / \text { the } \\
\text { difference between the mean and } 3.5 \text { is positive / } \\
\text { There is a statistical significance that the mean is } \\
\text { greater than } 3.5\end{array}$ \\
\hline Critical thinking score & 3.83 & 0.33 & 0.00 & $\begin{array}{l}\text { The P-value is less than } 0.05 / \text { the } \\
\text { difference between the mean and } 3.5 \text { is positive / } \\
\text { There is a statistical significance that the mean is } \\
\text { greater than } 3.5\end{array}$ \\
\hline
\end{tabular}


Table 4 shows that all means are lower than 3.5 (all $\mathrm{P}$ values are less than 0.05 ); to the exception of Question 14, it had a mean of 3.48 (and a P value greater that 0.05 ) and this means there is a statistical evidence that Citizens had Critical thinking except for when it came to consulting specialized doctors about this virus. Nevertheless, it is worth mentioning that this value if very close to the average mean of 3.5 .

Comparison of having critical thinking by Demographics

a. Comparison of the means for each criteria according to Gender

Figure 12. Means by Gender

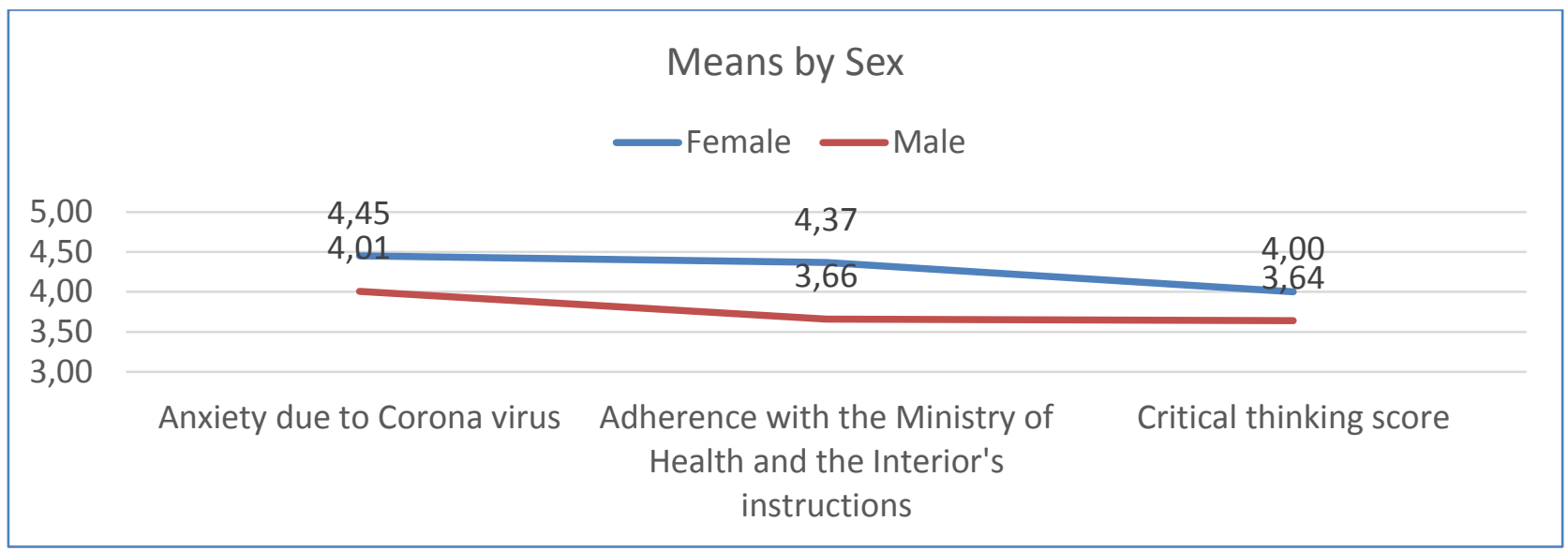

Figure 12 shows that females have more anxiety (mean of 4.45) because of Corona virus than males (mean 4.01). They have committed to the instructions of the ministry of Health and the ministry of Interior (mean of 4.37) more than men did (mean of 3.66), and they have the skill of critical thinking more than men do (mean of 4 for females compared to mean of 3.64 for males).

We have adopted the Independent Sample T-test to compare the means of 2 groups (males \& females) and see if the difference in means is significant.

Comparison of the means for each criteria according to Gender (Table 5.)

\begin{tabular}{|c|c|c|c|c|}
\hline Variable & Female & Male & $\begin{array}{l}\text { P- } \\
\text { value }\end{array}$ & Interpretation \\
\hline $\begin{array}{l}\text { Anxiety due to } \\
\text { Corona virus }\end{array}$ & 4.4 & 4.01 & 0.00 & $\begin{array}{cc}\text { The difference in means } & \text { Anxiety due to } \\
\text { between males and females is } & \text { corona virus is higher for } \\
\text { statistically significant } & \text { females }\end{array}$ \\
\hline $\begin{array}{l}\text { Adherence } \\
\text { with the } \\
\text { Ministry of } \\
\text { Health and the } \\
\text { Interior's } \\
\text { instructions }\end{array}$ & 4.7 & 3.66 & 0.00 & $\begin{array}{c}\text { The difference in means } \\
\begin{array}{c}\text { Adherence with the } \\
\text { between males and females is } \\
\text { Ministry of Health and the } \\
\text { statistically significant }\end{array} \begin{array}{c}\text { Interior's instructions is } \\
\text { higher for females }\end{array}\end{array}$ \\
\hline $\begin{array}{l}\text { Critical } \\
\text { thinking score }\end{array}$ & 4.0 & 3.64 & 0.00 & $\begin{array}{l}\text { The difference in means } \\
\text { between males and females is } \begin{array}{c}\text { Critical thinking } \\
\text { statistically significant }\end{array} \text { score is higher for females }\end{array}$ \\
\hline
\end{tabular}

Table 5 shows that there is a statistically significant relationship in the difference between males and females in the level of anxiety from Corona virus since $P$ value $=0.00$ which is lower than Alpha 0.05. Similarly, there is a statistically significant relationship in the difference between males and females 
in the level of commitment to the instructions of the ministry of Health and Interior during the crisis of Corona virus. We also notice that the skill of critical thinking is higher in females than it is in males.

When comparing the means for each criteria of the survey, we should take into consideration the following statistical rule:

- If the statistical significance for Levene Statistics is higher than 0.05, we use the Anova test to compare the means.

- If the statistical significance for Levene Statistics is lower than 0.05, we use the Welch test to compare the means.

b. Comparison of the means for each criteria according to Age Group

Comparison of the means for each criteria according to Age Group (Table 6.)

\begin{tabular}{|c|c|c|c|c|c|c|c|}
\hline Variable & $18-30$ & $31-40$ & $\begin{array}{c}41- \\
50\end{array}$ & $50+$ & $\begin{array}{c}\text { Statistical } \\
\text { test }\end{array}$ & P-value & Interpretation \\
\hline $\begin{array}{l}\text { Anxiety due to } \\
\text { Corona virus }\end{array}$ & 4.32 & 4.2 & .19 & 4.26 & Welch test & 0.48 & $\begin{array}{c}\text { The difference in means } \\
\text { between the age groups } \\
\text { is statistically } \\
\text { significant }\end{array}$ \\
\hline $\begin{array}{l}\text { Adherence with } \\
\text { the Ministry of } \\
\text { Health and the } \\
\text { Interior's } \\
\text { instructions }\end{array}$ & 4.18 & 4.0 & .09 & 3.53 & Welch test & 0.00 & $\begin{array}{c}\text { The difference in means } \\
\text { between the age groups } \\
\text { is statistically } \\
\text { significant }\end{array}$ \\
\hline $\begin{array}{l}\text { Critical thinking } \\
\text { score }\end{array}$ & 4.07 & 3.1 & .77 & 3.08 & Welch test & 0.00 & $\begin{array}{c}\text { The difference in means } \\
\text { between the age groups } \\
\text { is statistically } \\
\text { significant }\end{array}$ \\
\hline
\end{tabular}

Table 6 shows that there is no statistically significant relationship between the differences in the answers of the citizens of this research related to anxiety due to Corona virus compared to age range. This means that most answers were similar since $\mathrm{P}$ value $=0.48$; which is higher than Alpha 0.05. However, there was a statistically significant relationship between the age range of the respondents to this survey and the level of commitment to the instructions of the ministry of Health and ministry of Interior, since P value =0.00; which is lower than Alpha 0.05. We conclude that the influencing factor in the responses of the citizens was due to the availability of the Critical thinking skill in some of them.

c. Comparison of the means for each criteria according to Education

Comparison of the means for each criteria according to Age Group (Table 7)

\begin{tabular}{|c|c|c|c|c|c|c|c|}
\hline Variable & $18-30$ & $31-40$ & $41-50$ & $50+$ & Statistical test & P-value & Interpretation \\
\hline Anxiety due to Corona virus & 4.32 & 4.20 & 4.19 & 4.26 & Welch test & 0.48 & $\begin{array}{c}\text { The difference in means } \\
\text { between the age groups is } \\
\text { statistically significant }\end{array}$ \\
\hline $\begin{array}{l}\text { Adherence with the } \\
\text { Ministry of Health and the } \\
\text { Interior's instructions }\end{array}$ & 4.18 & 4.07 & 4.09 & 3.53 & Welch test & 0.00 & $\begin{array}{l}\text { The difference in means } \\
\text { between the age groups is } \\
\text { statistically significant }\end{array}$ \\
\hline Critical thinking score & 4.07 & 3.91 & 3.77 & 3.08 & Welch test & 0.00 & $\begin{array}{l}\text { The difference in means } \\
\text { between the age groups is } \\
\text { statistically significant }\end{array}$ \\
\hline
\end{tabular}


Table 7 shows that there is statistically significant relationship between the educational level of the citizens of the survey and anxiety from Corona virus as well as to their commitment to the instructions of the ministry of Health and the ministry of Interior; since P value for both criteria was lower than Alpha 0.05. As a result, we conclude that the influencing factor in the responses of the citizens was due to the availability of the Critical thinking skill in varying degrees.

d. Comparison of the means for each criteria according to Occupation

Comparison of the means for each criteria according to Occupation (Table 8.)

\begin{tabular}{|c|c|c|c|c|c|c|c|c|c|c|}
\hline Variable & $\begin{array}{l}\text { Public } \\
\text { Sector }\end{array}$ & $\begin{array}{l}\text { Private } \\
\text { Sector }\end{array}$ & Freelance & Retired & Unemployed & Student & $\begin{array}{c}\text { House } \\
\text { wife }\end{array}$ & Test & P-value & Interpretation \\
\hline $\begin{array}{l}\text { Anxiety due } \\
\text { to Corona } \\
\text { virus }\end{array}$ & 4.55 & 4.32 & 3.84 & 4.29 & 4.18 & 4.32 & 4.42 & $\begin{array}{c}\text { Welch } \\
\text { test }\end{array}$ & 0.00 & $\begin{array}{l}\text { The difference } \\
\text { in means } \\
\text { between the } \\
\text { occupation } \\
\text { groups is } \\
\text { statistically } \\
\text { significant }\end{array}$ \\
\hline $\begin{array}{l}\text { Adherence } \\
\text { with the } \\
\text { Ministry of } \\
\text { Health and } \\
\text { the Interior's } \\
\text { instructions }\end{array}$ & 4.16 & 4.23 & 3.58 & 3.30 & 4.03 & 4.30 & 4.28 & Anova & 0.00 & $\begin{array}{l}\text { The difference } \\
\text { in means } \\
\text { between the } \\
\text { occupation } \\
\text { groups is } \\
\text { statistically } \\
\text { significant }\end{array}$ \\
\hline $\begin{array}{c}\text { Critical } \\
\text { thinking } \\
\text { score }\end{array}$ & 4.07 & 3.99 & 3.71 & 2.85 & 3.69 & 4.12 & 3.79 & $\begin{array}{c}\text { Welch } \\
\text { test }\end{array}$ & 0.00 & $\begin{array}{l}\text { The difference } \\
\text { in means } \\
\text { between the } \\
\text { occupation } \\
\text { groups is } \\
\text { statistically } \\
\text { significant }\end{array}$ \\
\hline
\end{tabular}

Table 8 shows that there is a statistically significant relationship between the Occupation of the respondents and their answers regarding anxiety from Corona virus as well as to their commitment to the instruction of the ministry of Health and the ministry of Interior; since P value of both criteria was lower than Alpha 0.05. Having the skill of critical thinking plays a major role in the responses of the citizens in comparison to their Profession. And this is totally logical because the individual acquires the critical thinking skill from the experiences he/she gets in the market.

e. Comparison of the means for the effect of Corona virus on work according to Occupation.

Comparison of the means for the effect of Corona virus on work according to Occupation (Table 9)

\begin{tabular}{lccccc}
\hline $\begin{array}{c}\text { Public sector Private sector } \\
\text { employee }\end{array}$ & employee & Freelance & Test & P-value & Interpretation \\
\hline 2.21 & 2.88 & 3.04 & Welch & 0.00 & $\begin{array}{c}\text { The difference in means between the } \\
\text { occupation groups is statistically } \\
\text { significant }\end{array}$ \\
\hline
\end{tabular}


Table 9 shows that the responses of working citizens on the effect of Corona virus on their work differed from self-employed citizens to the employees of the public sector, to the employees of the private sector. The most affected were the self-employed (having a mean of 3.04). Next, were the employees of the private sector who had a mean of 2.88. And finally, the employees of the public sector were the least affected - with a mean of 2.21. Nevertheless, the P value for all 3 profession types was lower than Alpha 0.05; which means there is a statistically significant relationship among the variables.

f. Comparison of the means for each criteria according to Chronic diseases

Figure 13. Comparison of the means for each criteria according to Chronic diseases

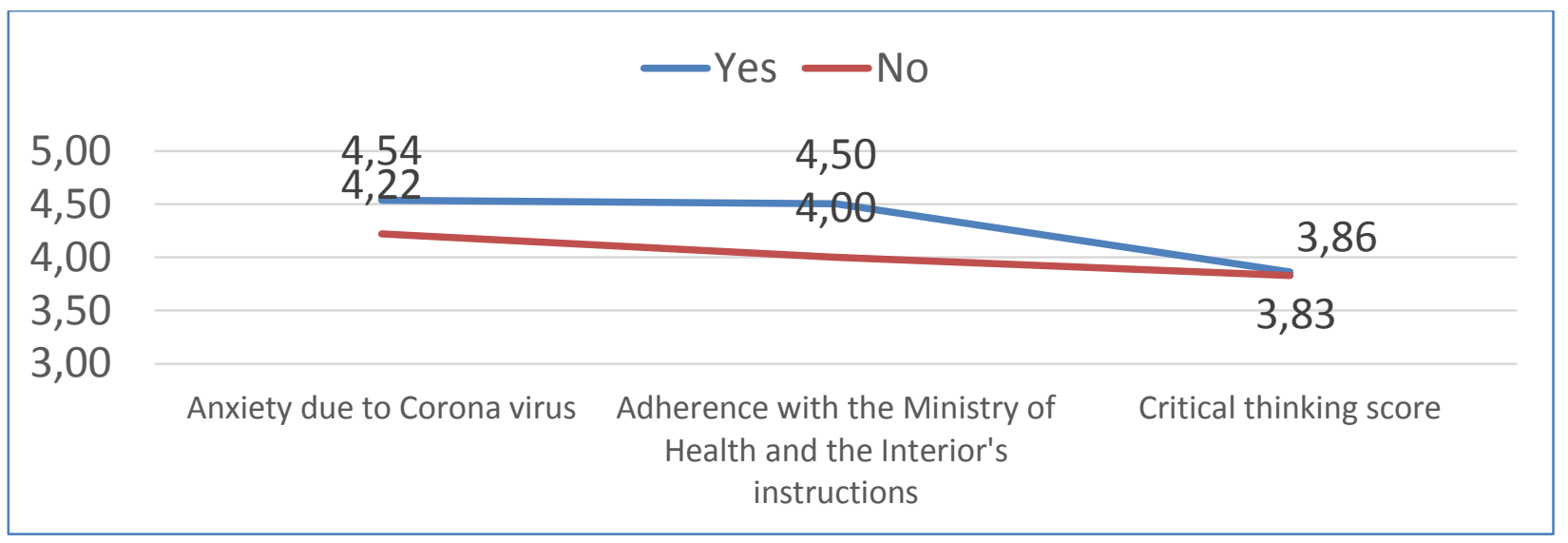

Figure 13 shows that citizens who had chronic disease had more anxiety because of Corona virus (mean of 4.54 which is closer to 5), as well as they were committed to the instructions of both ministries of Health and Interior (mean of 4.50), while their Critical thinking had a close mean to those citizens who did not suffer from chronic diseases (3.86 compared to 3.83).

g. Comparison of the means for the commitment to the instructions of both ministries of Health and Interior according to chronic diseases

Comparison of the means for the commitment to the instructions of both ministries of Health and Interior according to chronic diseases (Table 10)

\begin{tabular}{|c|c|c|c|c|c|}
\hline Variable & yes & No & P-value & Interpretation & \\
\hline $\begin{array}{c}\text { Anxiety due to Corona } \\
\text { virus }\end{array}$ & 4.54 & 4.22 & 0.02 & $\begin{array}{l}\text { The difference in means } \\
\text { between the two groups is } \\
\text { statistically significant }\end{array}$ & $\begin{array}{c}\text { Anxiety due to corona } \\
\text { virus is higher in patients } \\
\text { who suffer from chronic } \\
\text { disease }\end{array}$ \\
\hline $\begin{array}{l}\text { Adherence with the } \\
\text { Ministry of Health and } \\
\text { the Interior's } \\
\text { instructions }\end{array}$ & 4.50 & 4.00 & 0.00 & $\begin{array}{l}\text { The difference in means } \\
\text { between the two groups is } \\
\text { statistically significant }\end{array}$ & $\begin{array}{l}\text { Adherence with the } \\
\text { Ministry of Health and } \\
\text { the Interior's instructions } \\
\text { is higher in patients who } \\
\text { suffer from chronic } \\
\text { disease }\end{array}$ \\
\hline Critical thinking score & 3.86 & 3.83 & 0.83 & $\begin{array}{l}\text { The difference in means } \\
\text { between the two groups is } \\
\text { statistically significant }\end{array}$ & $\begin{array}{l}\text { Critical thinking score is } \\
\text { higher in patients who } \\
\text { suffer from chronic } \\
\text { disease }\end{array}$ \\
\hline
\end{tabular}


Table 10 shows that there is no statistically significant relationship between having the skill of critical thinking and those citizens having chronic diseases since $P$ value $=0.83$, which is higher than Alpha 0.05. In other words, it does not change their answers to anxiety from Corona virus or their commitment to the instructions of both ministries of Health and Interior.

h. Comparison of the means for each criteria according to Marital status

Comparison of the means for each criteria according to marital status (Table 11)

\begin{tabular}{|c|c|c|c|c|c|c|c|}
\hline Variable & Single & Married & $\begin{array}{l}\text { Divor } \\
\text { ced }\end{array}$ & $\begin{array}{l}\text { Wido } \\
\text { wed }\end{array}$ & ${ }^{T}{ }_{\text {est }}$ & P-value & Interpretation \\
\hline $\begin{array}{l}\text { Anxiety due to } \\
\text { Corona virus }\end{array}$ & 4.27 & 4.24 & 3.68 & 4.91 & N elch & $\begin{array}{l}0.0 \\
0\end{array}$ & $\begin{array}{l}\text { The difference in means between marital } \\
\text { status groups is statistically significant }\end{array}$ \\
\hline $\begin{array}{l}\text { Adherence with } \\
\text { the Ministry of } \\
\text { Health and the } \\
\text { Interior's } \\
\text { instructions }\end{array}$ & 4.09 & 4.07 & 3.79 & 3.18 & $\begin{array}{l}\text { A } \\
\text { nova }\end{array}$ & $\begin{array}{l}0.0 \\
0\end{array}$ & $\begin{array}{l}\text { The difference in means between marital } \\
\text { status groups is statistically significant }\end{array}$ \\
\hline $\begin{array}{l}\text { Critical thinking } \\
\text { score }\end{array}$ & 4.01 & 3.86 & 3.14 & 2.32 & elch & $\begin{array}{l}0.0 \\
0\end{array}$ & $\begin{array}{l}\text { The difference in means between marital } \\
\text { status groups is statistically significant }\end{array}$ \\
\hline
\end{tabular}

Table 11 shows that the answers of the citizens regarding anxiety from Corona virus and their commitment to the instructions of both ministries of Health and Interior differ according to marital status; we notice that the most committed were the widowed citizens, followed by the single citizens, then married citizens, to the divorced citizens. Yet, all citizens' answers were affected by the level of critical thinking they had, since P value for all criteria was lower than Alpha 0.05.

i. Comparison of the means for each criteria according to Governorate

Comparison of the means for each criteria according to Governorate (Table 12)

\begin{tabular}{|c|c|c|c|c|c|c|c|c|c|c|c|}
\hline Variable & Beirut & $\begin{array}{l}\text { Mount } \\
\text { lebanon }\end{array}$ & Bekaa & $\begin{array}{l}\text { Baalback } \\
\text {-Hermel }\end{array}$ & North & Akkar & South & Nabatieh & Test & P-value & Interpretation \\
\hline $\begin{array}{l}\text { Anxiety due to } \\
\text { Corona virus }\end{array}$ & $\begin{array}{l}4.5 \\
0\end{array}$ & 4.41 & 4.4 & 4.0 & 3.8 & 4.2 & 4.0 & 4.1 & Welch test & 0.00 & $\begin{array}{c}\text { The difference in means } \\
\text { between governorates } \\
\text { is statistically } \\
\text { significant }\end{array}$ \\
\hline $\begin{array}{l}\text { Adherence } \\
\text { with the } \\
\text { Ministry of } \\
\text { Health and the } \\
\text { Interior's } \\
\text { instructions }\end{array}$ & 4.4 & 4.37 & 3.9 & 3.0 & 3.3 & 3.5 & 4.0 & 4.2 & Welch test & 0.00 & $\begin{array}{c}\text { The difference in means } \\
\text { between governorates } \\
\text { is statistically } \\
\text { significant }\end{array}$ \\
\hline $\begin{array}{l}\text { Critical } \\
\text { thinking score }\end{array}$ & $\begin{array}{l}4.1 \\
\quad 9\end{array}$ & 4.05 & 3.5 & 2.8 & 3.4 & 3.7 & 3.5 & 4.1 & Welch test & 0.00 & $\begin{array}{c}\text { The difference in means } \\
\text { between governorates } \\
\text { is statistically } \\
\text { significant }\end{array}$ \\
\hline
\end{tabular}

Table 12 shows that there is a statistically significant relationship between the availability of Critical thinking and citizens in different governorates since the P value is lower than Alpha 0.05. As for the level of commitment to the instructions of both ministries of Health and Interior and being anxious due to Corona virus, citizens in all governorates were committed and were anxious (all means being 
above 3 - which is Neutral); yet, their level of commitment and anxiety varied among governorates. Below graph clarifies the differences:

Figure 14. Comparison of the means for each criteria according to Governorate

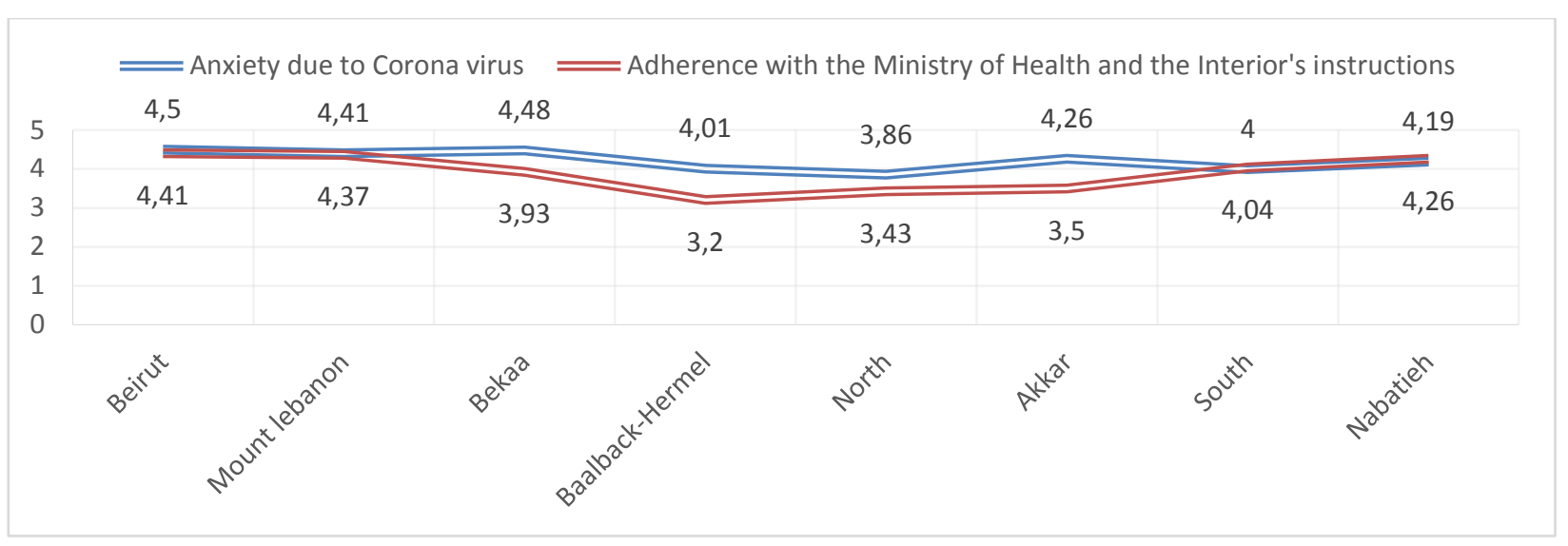

\section{Relationship between the independent variable and the dependent variables}

We have studied the relationship between the skill of critical thinking (being the independent variable) and anxiety caused by Corona virus (being dependent variable 1) and commitment to the instructions of both ministries of Health and Interior (being dependent variable 2) by using the statistical test named Pearson Correlation test.

Relationship between the independent variable and the dependent variables (Table 13)

\begin{tabular}{ccccc}
\hline $\begin{array}{c}\text { Independent } \\
\text { Variable }\end{array}$ & Dependent Variable & $\begin{array}{c}\text { Pearson } \\
\text { Correlation-r }\end{array}$ & P-value & Interpretation \\
\hline $\begin{array}{c}\text { Critical } \\
\text { thinking }\end{array}$ & $\begin{array}{c}\text { Anxiety due to Corona } \\
\text { virus }\end{array}$ & 0.42 & 0.00 & $\begin{array}{c}\text { Positive-Moderate-significant } \\
\text { correlation }\end{array}$ \\
$\begin{array}{c}\text { Critical } \\
\text { thinking }\end{array}$ & $\begin{array}{c}\text { Ministry of Health and the } \\
\text { Interior's instructions }\end{array}$ & 0.61 & 0.00 & $\begin{array}{c}\text { Positive-Strong-significant } \\
\text { correlation }\end{array}$ \\
\hline
\end{tabular}

Table 13 shows that there is a positive yet medium $(r=0.42)$ relationship between citizens having the skill of critical thinking and their anxiety level. Also, there is a positive yet strong (0.61) relationship for citizens having the skill of critical thinking and their commitment level to the instructions of both ministries of Health and Interior. In comparing the two dependent variables, we notice that Critical thinking decreased anxiety to Corona virus, yet increase the level of commitment among citizens of the survey.

\section{CONCLUSION an d SUGGESTIONS}

Decisions we make affect the quality of our life. By achieving our goals and aspirations and overcoming the obstacles and crisis we face by taking the right matured decision, we make sure that we are living successfully. Through critical thinking, we allow ourselves to come up with new innovated ideas to solve problems. The field research has proved that the availability of critical thinking in a good portion of individuals in our society has come up with a social benefit to all Lebanese society, because this had helped governorates limit and contain the spread of Corona virus, and thus decrease the resulting anxiety and tension. Therefore, our mind should be challenged and trained exactly as our muscles, to become strong. It is worth comparing the skill of critical 
thinking to an activity of the mind- that has to be practiced. Critical thinking enhances many other skills like logical-thinking, decision-making, and openness. Critical thinking skill is improved by identifying the question, gathering reliable information, and seeking to explore the different aspects of the problem we face, as there is no one simple answer. By exploring all options available, we reach logical and correct conclusion by thinking outside the box. A better understanding of the Critical thinking skill would have occurred if the sample had covered different countries afflicted with Corona virus and not just Lebanon. The levels of critical thinking fluctuate from person to another; it would be interesting to know how other people in other countries think and act about this epidemic and how objective were they in their decisions in facing it.

Based on the above, science is the only weapon capable to face and overcome such emerging crises, especially epidemiological ones; therefore, we suggest the following:

Focus on building multiple skills more than building knowledge in a single area.

Invest in logistical capabilities and its related technology.

Develop technical skills; which is now available in all disciplines and find ways for improving it.

Enable nad support the analytical skills which cannot be performed by machines whilst humans can do.

Work on improving and developing the scientific research centers.

Focus on self-learning, sequencing, analysis, and results.

Analyze the crisis we are victims to, in order to know its purpose and work on preventing its reoccurrence through taking advantage of our current situation.

Develop scientific prediction methods through symmetry and projection by context.

Similarly, we suggest that future studies focus on anything that enhancing students skills and improve it, and be beneficial to our society as follows:

The relationship between artificial intelligence, robotics and automation and the development of societies.

Focus on studies that relate to Biological sciences.

Look for anticipating crisis that may hit the country through specific scenarios.

Further develop researches in which an individual is capable to identify problems before their occurrence and get ready for preventing or facing it.

Train the human mind to consider all possible options available to a problem through intellectual imagination, regardless of the probability of occurrence.

\section{REFERENCES}

Cottrell, S. (2011). Critical thinking skills: Developing effective analysis and argument. New York, NY: MacMillan.

Havigerová, J. M. (2011). Pět pohledů na nadání. Praha: Grada.

Hopkins, C., Surda, P., \& Kumar, N. (2020). Presentation of new onset anosmia during the COVID-19 pandemic. Rhinology, 10.

Lemon, S. M., Hamburg, M. A., Sparling, P. F., Choffnes, E. R., \& Mack, A. (2008). Ethical and legal considerations in mitigating pandemic disease, summary workshop. In Ethical and legal considerations in mitigating pandemic disease, summary workshop. National Academies Press.

Levinson, S. C. (2016). Turn-taking in human communication-origins and implications for language processing. Trends in cognitive sciences, 20(1), 6-14.

Lohrmann, D. K. (2011). Thinking of a change: health education for the 2020 generation. American Journal of Health Education, 42(5), 258-269.

Makhzoum, V. (2020). Corona virus on social media. http://snaatv.com/ 08/03/2020/3396/.

Paul, R., \& Elder, L. (2019). A guide for educators to critical thinking competency standards: Standards, principles, performance indicators, and outcomes with a critical thinking master rubric. Rowman \& Littlefield.

Petty, G. (2009). Evidence-based teaching: A practical approach. Cheltenham: Nelson Thornes. 
Rainbolt, G. W., \& Dwyer, S. L. (2014). Critical thinking: The art of argument. Cengage Learning.

Sogunro, O. A. (2002). Selecting a quantitative or qualitative research methodology: An experience. Educational Research Quarterly, 26(1), 3.

Van Den Brink-budgen, R. (2010). Critical thinking for students: Learn the skills of analysing, evaluating and producing arguments. How To Books. 